\title{
CHANGES OF PROTEIN PROFILES IN PORK AND BEEF MEAT CAUSED BY HIGH HYDROSTATIC PRESSURE TREATMENT
}

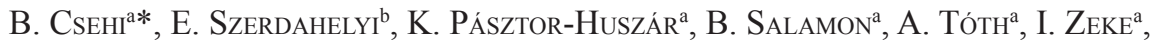 \\ G. JÓNÁs ${ }^{\mathrm{a}}$ and L. FRIEDRICH ${ }^{\mathrm{a}}$ \\ ${ }^{a}$ Department of Refrigeration and Livestock Products Technology, Faculty of Food Science, Szent István \\ University, H-1118 Budapest, Ménesi út. 43-45. Hungary \\ ${ }^{\mathrm{b}}$ Department of Biology, Food Science Research Institute, National Agricultural Research and Innovation Centre, \\ H-1022 Budapest, Herman Ottó út 15. Hungary
}

(Received: 23 March 2016; accepted: 21 August 2016)

\begin{abstract}
In the experiments pork loin and beef sirloin were treated by pressures of 100 to $600 \mathrm{MPa}$ by $100 \mathrm{MPa}$ steps for 5 min. Colour changes of samples and the changes of proteins were investigated. The latter were examined with isoelectric focusing and SDS polyacrylamide gel electrophoresis. We found that myoglobin behaved completely differently in case of the two different species. Myoglobin has mostly lost its native state at $300 \mathrm{MPa}$ pressure in case of pork, but the beef myoglobin could remain native even up to $500 \mathrm{MPa}$. The treatment at $300 \mathrm{MPa}$ or higher pressure values caused almost complete aggregation and denaturation in case of pork and beef proteins. The results of SDS-PAGE and the colour measurement confirmed this finding.
\end{abstract}

Keywords: pork and beef meat, high pressure, colour, protein profile, electrophoresis

The increase of animal-based protein (ABP) consumption has started worldwide about 50 years ago. Composition of ABPs and role of meat within this category is different among countries (SANS \& COMBRIS, 2015). The consumption of beef and pig meat is significant all over the world. Proteins in meat have high biological value and represent an important source of animal proteins in human nutrition (PARUNOvić et al., 2012; GulYÁs et al., 2015). In the food industry, high pressure processing (HHP), as a non-thermal treatment (GROssI et al., 2016), is mainly used for shelf-life extension by microbial inactivation (MoreIRA et al., 2015). HHP treatment is an alternative technology, because the retention of nutritional and organoleptic characteristics is better compared to thermal processing (CHERET et al., 2005). As a result of high pressure, protein molecules undergo structural changes by getting to different states of unfolding and denaturation. In consequence of these new protein conformations, their functional characteristics such as coagulation, aggregation, or gelation are modified (Cheftel \& Culioli, 1997; IwASAKi et al., 2006).

Protein susceptibility to high pressure and treatment parameters (pressure, temperature, and the duration of the pressure treatment) affects the result (Sun \& Holley, 2010). Colour of meat is also altered by high pressure treatment, in part owing to changes in myoglobin constitution (BAK et al., 2014). High hydrostatic pressure (HHP) treatment of foods can also modify protein structure and activity (Ko et al., 2003; CHERET et al., 2005), but the proteins react differently to the magnitude of pressure, moreover there are differences between some species. It is essential to the development of technological processes that we know the qualitative changes of proteins of different species generated by high hydrostatic pressure treatment.

\footnotetext{
* To whom correspondence should be addressed. Phone: +36-1-3507060; e-mail: Csehi.Barbara@etk.szie.hu
} 


\section{Materials and methods}

\subsection{Meat samples}

Fresh beef sirloin and pork loin were purchased in a local meat shop. All measurements were carried out in triplicate, and each sample originated from a different animal. Meat was cleaned from the fat and the connective tissue and was stored refrigerated at $4 \pm 1{ }^{\circ} \mathrm{C}$. The samples were vacuum packed in polyethylene (Cryovac ${ }^{\mathcal{O}}$, BB4L) package.

\subsection{High hydrostatic pressure}

The samples were treated in a Resato FPU-100-2010 (Resato International B.V, The Netherlands) equipment for $5 \mathrm{~min}$ at six different pressure values: $0 \mathrm{MPa}$ (control sample without treatment), 100, 200, 300, 400, 500, and $600 \mathrm{MPa}$. The initial temperature of the samples was $1-3{ }^{\circ} \mathrm{C}$, and due to the adiabatic heating, samples' temperature increased by approximately $3{ }^{\circ} \mathrm{C} / 100 \mathrm{MPa}$. After the treatment, the colour measurements were performed with a Minolta CR-400 (Konica Minolta, Japanese) tristimulus colorimeter.

\subsection{Extraction of muscle proteins}

The method of KRETZSCHMAR (1995) was used for the extraction of meat proteins for the SDSPAGE. For the extraction of sarcoplasmic and myofibrillar proteins we have milled the control and treated samples in a cutter. We have measured $1 \mathrm{~g}$ from each sample, then added $2 \mathrm{ml}$ of $0.05 \mathrm{M} \mathrm{NaCl}$ solution and homogenized the mixture (Ultra-Turrax T25, Ika Werk, Staufen, Germany) at 13500 r.p.m. for 3 min. Samples were cooled in ice during homogenization. The homogeneous suspension was centrifuged at $10000 \mathrm{~g}$ (Beckman J2-21, California, USA) for $15 \mathrm{~min}$ then filtered $\left(4^{\circ} \mathrm{C}\right)$. The supernatant contained the sarcoplasmic proteins. The precipitate was washed with $0.05 \mathrm{M} \mathrm{NaCl}$ solution once to extract the myofibrillar proteins. The supernatant was removed, then $2 \mathrm{ml}$ of $0.7 \mathrm{M} \mathrm{NaCl}$ solution was added to the washed precipitate and homogenized (Ultra-Turrax T25, Ika Werk, Staufen, Germany) for 1 min. After homogenization, the samples were centrifuged for $15 \mathrm{~min}$ and the reduced supernatant was filtered. This filtered supernatant contained the myofibrillar proteins. The method described by Hajós and Delincée (1983) was used for the extract preparation for isoelectric focusing.

\subsection{Electrophoresis (SDS-PAGE)}

Four to fifteen percent handcast gels (acrylamid/bis-acrylamid, $830 \times 730 \times 1.0 \mathrm{~mm}$ ) were used for the electrophoresis and the vertical system was applied during the measurement (Bio-Rad mini Protein Tetra System, Bio-Rad, USA). The range of molecular standard (Precision Plus Protein Standards All Blue, Bio-Rad, USA) was 250-10 kDa. The sample extracts were prepared by dilution with the sample buffer $(2 \times$ Laemmli sample buffer and 2 -mercaptoethanol, Bio-Rad, USA). In case of beef and pork, sarcoplasmic proteins 20 -fold dilution was used, while for myofibrillar proteins, 2-fold dilution. From the dilutions, $10 \mu \mathrm{l}$ of protein solutions were loaded into the wells. Gels were stained for 30 min with $0.2 \%$ Coomassie Brilliant Blue (R250, Bio-Rad). Stained gel images were captured using a Gel Doc XR+ System (Bio-Rad). The densities of the bands were quantified by using Quantity One software program (BioRad). Their densities were expressed as relative intensity, where the results of HHP treated samples were compared to the intensity of control samples, calculated in percentage. 


\subsection{Electrophoresis (Isoelectric focusing)}

We used $12 \times 12 \mathrm{~cm}$ agarose gel during the isoelectric focusing. The $\mathrm{pH}$ range of added ampholyte was $5-8$. The anode solution was $1 \%$ sulphuric acid, and the cathode solution was ethylene diamine. The used standard was horse myoglobin (myoglobin (horse skeletal muscle), Calbiochem, USA). The specific dyeing of the hemeproteins was accomplished on the basis of BAUER and HoFmANN's process (1987).

\section{Results and discussion}

\subsection{Colour measurement}
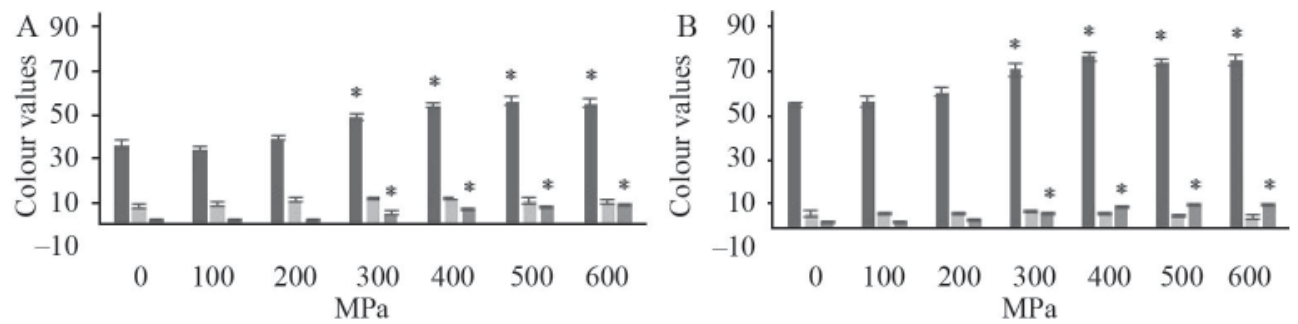

Fig 1. Results of beef sirloin and pork loin colour measurement. (Asterisk marks the significant changes. The confidence level was 95\%). $\mathrm{a}: \mathrm{L}^{*} ;$ : $: \mathrm{a}^{*}$; $\sqsubset$ : $\mathrm{b}^{*}$ A: Beef sirloin colour; B: pork loin colour

The colour of the treated and control samples was measured in triplicate, and each parallel sample was measured at ten different points. Figure 1 represents the results of colour measurements, standard deviations are indicated with the bars on the top of the columns. In case of both types of meats, a 'jump' was observed in the L* values at $300 \mathrm{MPa}$ caused by the treatment, therefore this pressure can be regarded as a threshold. This increase in the values was over $30 \%$ compared to the control samples. The one-way analysis of variance (ANOVA) proved that the HHP treatment influenced significantly the L* values, because the P-value of test was 0.000 and the value of R squared was 0.914 (the confidence level was $95 \%$ ). It was observable even for the human eye as the colour of the samples became lighter and pale.

The $\mathrm{a}^{*}$ value of treated beef and pork meat did not change significantly. The ANOVA showed that the effect of treatment is not significant (P-value: 0.124$)$ in case of a* values. In the $b^{*}$ values we also experienced remarkable growth, the values at higher (400-600 MPa) pressures were two to three times higher than at lower (100-300 MPa) pressures (P-value of ANOVA was 0.000 and the R squared was 0.954 ).

\subsection{Effects of high pressures on protein profile}

The analysis of protein solubility is essential, because the change of solubility affects the functional properties and qualitative parameters, too (Joo et al., 1999). The proteins in meat (sarcoplasmic and myofibrillar) change during the high pressure treatment (MARCos et al., 2010), due to aggregation and denaturation (GALAZKA et al., 2000; IwASAKI et al., 2006). At the same time, the changes in proteins depend on some environmental conditions, which are not fully understood yet (BucKOw et al., 2013). 
The changes of myofibrillar proteins of beef sirloin and the samples treated by high pressure (from $100 \mathrm{MPa}$ to $600 \mathrm{MPa}$ ) are shown in Figure 2.
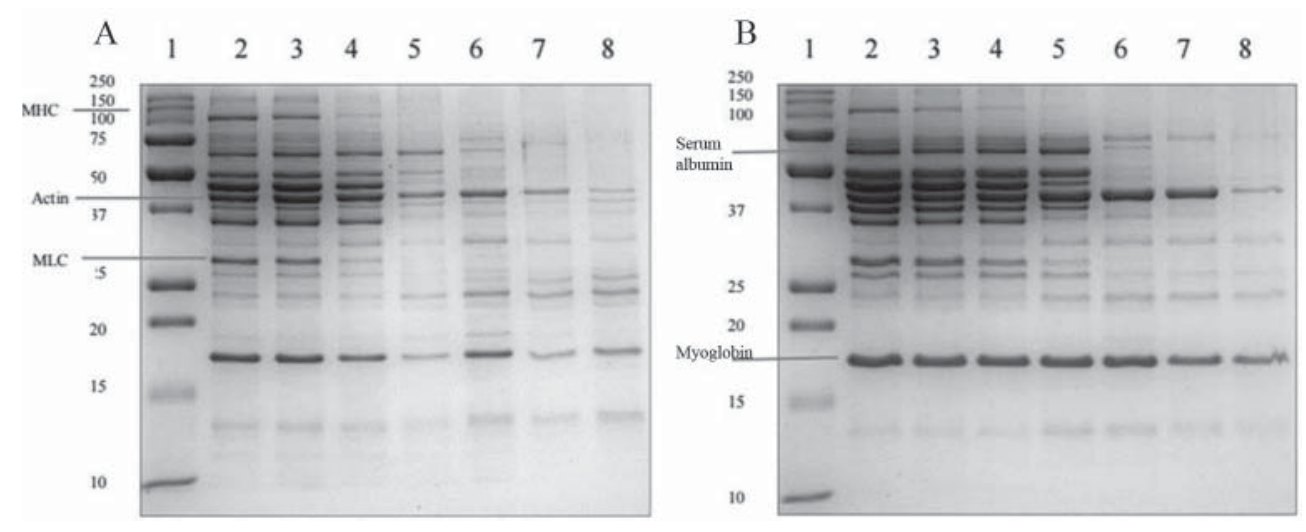

Fig. 2. Results of SDS-PAGE of beef sirloin (A: myofibrillar proteins, B: sarcoplasmic proteins) 1. Standard, 2. $0 \mathrm{MPa}$, 3. $100 \mathrm{MPa}$, 4. $200 \mathrm{MPa}$, 5. $300 \mathrm{MPa}$, 6. $400 \mathrm{MPa}$, 7. $500 \mathrm{MPa}, 8.600 \mathrm{MPa}$

The first column is the molecular standard, which makes the identification of proteins possible from $250 \mathrm{kDa}$ to $10 \mathrm{kDa}$. The largest volume of myofibrillars (54\%) is formed by myosin, which has two heavy and three light chains. Figure 2 shows that the light and heavy chains (MLC and MHC) of myosin from myofibrillar proteins mostly aggregated and denatured due to the pressure treatment, while in contrast, actin could be detected even after $600 \mathrm{MPa}$ pressure treatment. In case of lower pressures (100 and $200 \mathrm{MPa})$, the volume (intensity) of myofibrillar proteins (SDS-PAGE) was similar to that of the control sample, but in case of higher pressures (300 MPa or higher), the volume of proteins reduced by more than $50 \%$, therefore the $300 \mathrm{MPa}$ can be regarded as a threshold value. The reduction of intensity is caused by the aggregation resulting from the treatment.

The results of SDS-PAGE of sarcoplasmic proteins of beef sirloin can be seen in part B of Figure 2. Most enzymes of the glycolytic pathway and the myoglobin belong to the sarcoplasmic proteins (TORnBERG, 2005). Most sarcoplasmic proteins are soluble in water. One of the main sarcoplasmic proteins is the myoglobin (as a natural pigment), which gives the colour of meats, hence its analysis is essential. The intensity of myoglobin reduced in case of higher pressure values (500 and $600 \mathrm{MPa}$ ). At lower pressure values (from $0 \mathrm{MPa}$ to $400 \mathrm{MPa}$ ), the intensity of this band did not change, but at $500 \mathrm{MPa}$ pressure, the intensity reduced by $30 \%$. At $600 \mathrm{MPa}$, the rate of reduction was more than $45 \%$. During the treatment, conformational changes happen in the myoglobin of fresh meats, for example the denaturation of globin or the oxidation of ferrous ions, which can cause decolourization of meat (TOLDRÁ et al., 2008). According to BEKHIT and his co-workers (2003), the decolourization of meat is closely related to the spontaneous changes of myoglobin. Most of the proteins were partially or completely aggregated and denatured at $300 \mathrm{MPa}$ or higher pressure values. 

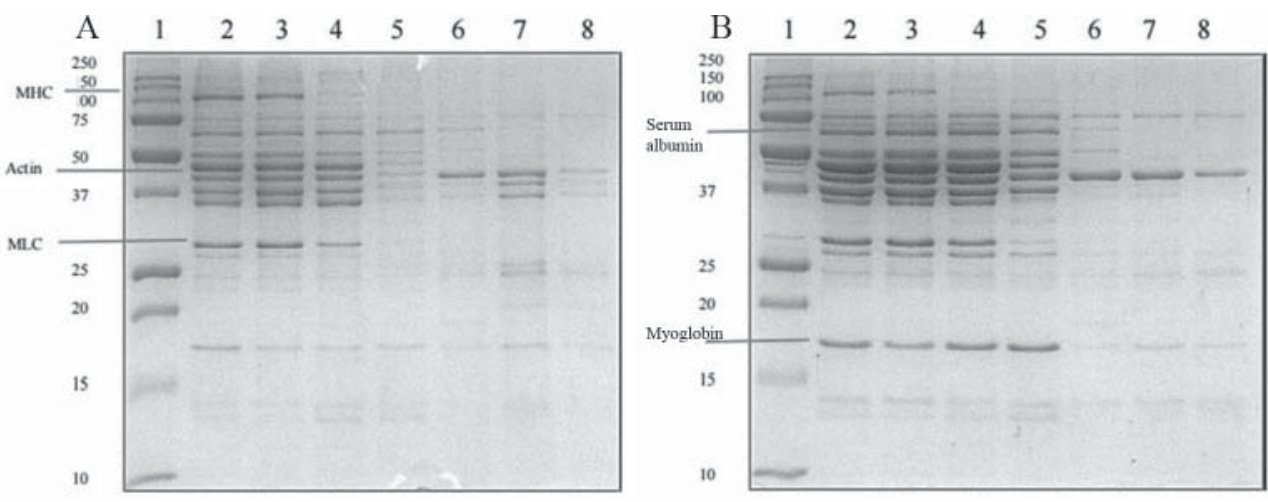

Fig. 3. Results of SDS-PAGE of pork loin (A: myofibrillar proteins, B: sarcoplasmic proteins) 1. Standard, 2. 0 MPa, 3. $100 \mathrm{MPa}$, 4. $200 \mathrm{MPa}$, 5. $300 \mathrm{MPa}$, 6. $400 \mathrm{MPa}$, 7. $500 \mathrm{MPa}$, 8. $600 \mathrm{MPa}$

The results of SDS-PAGE of myofibrillar and sarcoplasmic proteins of pork are shown in Figure 3. Results indicate that the protein profile is similar to the beef samples, light and heavy chains (MLC and MHC) of myosin mostly aggregated and denatured due to the pressure treatment, so they could not be brought into solution, hence the bands faded or disappeared in the gel. The largest change was found in case of myoglobin among the pork sarcoplasmic proteins. The bands of myoglobin were reduced by more than $80 \%$ due to the high (400 MPa or above) pressure treatment. In every case (beef myofibrillar and sarcoplasmic proteins and pork myofibrillar and sarcoplasmic proteins) the ANOVA proved that the treatment caused decreasing of intensity of bands. The P-values of test were 0.000 and the values of $\mathrm{R}$ squared were higher than 0.86 .

The electrophoretic methods in meat science are primarily used for the detection of unknown proteins or identification of species, and these methods are successfully applied for the detection of changes caused by industrial technologies of muscle proteins. In the analysis, isoelectric focusing (IEF) with specific pseudo-peroxidase dye is used for the detection of the effect of high pressure treatment. During the IEF, the proteins are in native status, hence the possible changes can be easily detected. As myoglobin partially denatured due to high hydrostatic pressure treatment, it has lost its native state, thus it could not be stained by the specific dye. Figure 4 (A) shows that the heme proteins are detected at isoelectric points (7.2; 6.8 and 6.4) typical of beef with the specific dye (HoffmAnN \& BLÜCHEL, 1986).

Intensity of bands was reduced especially in the samples treated by 500 or $600 \mathrm{MPa}$. Moreover, new, smaller bands appeared above the bands of myoglobin in case of $300 \mathrm{MPa}$ or higher pressure values, likely owing to the decomposition products. 


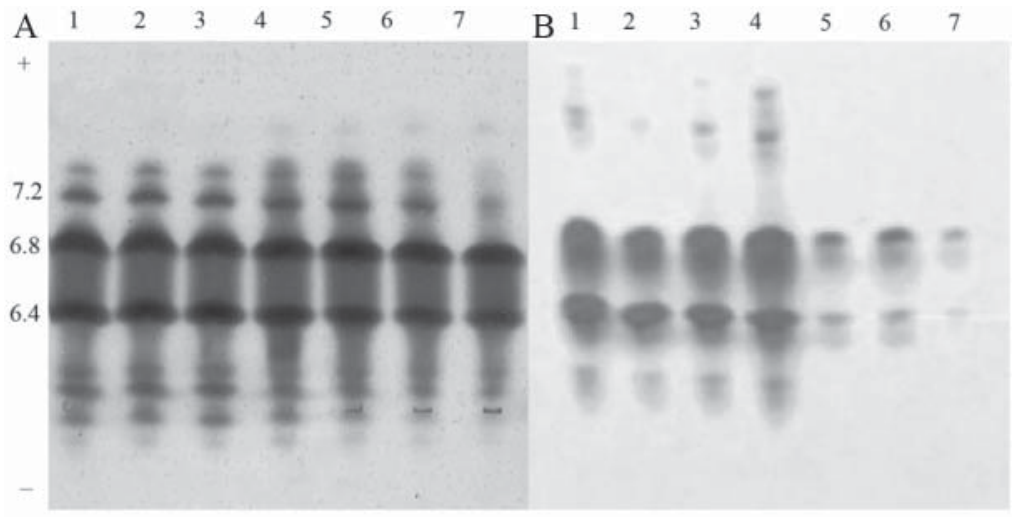

Fig. 4. Results of isoelectric focusing of beef sirloin and pork loin 1. Control, 2. $100 \mathrm{MPa}$, 3. $200 \mathrm{MPa}$, 4. $300 \mathrm{MPa}, 5.400 \mathrm{MPa}, 6.500 \mathrm{MPa}, 7.600 \mathrm{MPa}$

In case of pork (Fig. 4B), the main difference was that the myoglobin mainly lost its native state already above $300 \mathrm{MPa}$.

\section{Conclusions}

According to the results, pork and beef have reacted differently to pressure treatment. The myoglobin has mainly lost its native state at $300 \mathrm{MPa}$ pressure in case of pork, but the beef myoglobin remained native up to $500 \mathrm{MPa}$. The treatment at $300 \mathrm{MPa}$ or higher pressure values caused nearly complete aggregation and denaturation of proteins in case of pork and beef. These results were confirmed also by colour measurement.

\section{References}

BaK, K.H., Thulstrup, P.W. \& Orlien, V. (2014): Spectroscopic studies on the effect of high pressure treatment on the soluble protein fraction of porcine longissimus dorsi. Food Chem., 148, 120-123.

Bauer, F. \& Hofmann, K. (1987): Elektrophoretische Tierartbestimmung - Steigerung der Empfindlichkeit durch Peroxidasefarbung der Myoglobine. Fleischwirtschaft, 67, 861-867.

Bekhit, A.E.D., Geesink, G.H., Ilian, M.A., Morton, J.D., Sedcole, R. \& Bickerstaffe, R. (2003): Particulate metmyoglobin reducing activity and its relationship with meat colour. J. Agr. Food Chem., 51, 6026-6035.

Buckow, R., Sikes, A. \& Tume, R. (2013): Effect of high pressure on physicochemical properties of meat. Crit. Rev. Food Sci. Nutr., 53, 770-786.

Cheftel, J.C. \& Culioli, J. (1997): Effects of high pressure on meat: A review. Meat Sci., 46(3), 211-236.

Cheret, R., Delbarre-Ladrat, C., Lamballerie-Anton, M. \& Verrez-Bagnis, V. (2005): High-pressure effects on the proteolytic enzymes of sea bass (Dicentrarchus labrax L.) fillets. J. Agr. Food Chem, 53, 3969-3973.

Galazka, V.B., Dickinson, E. \& Ledward, D.A. (2000): Influence of high pressure processing on protein solutions and emulsions. Curr. Opin. Colloid In., 5(3-4), 182-187.

Grossi, A., Olsen, K., Bolumar, T., Rinnan, Å., Øgendal, L.H. \& Orlien, V. (2016): The effect of high pressure on the functional properties of pork myofibrillar proteins. Food Chem., 196, 1005-1015.

Gulyás, G., Czeglédi, L., Béri, B., Harangi, S., Csösz, E., Szabó, Z., JanÁky, T. \& Jávor, A. (2015): Proteomic analysis of skeletal muscle at different live weights in Charolais bulls. Acta Alimentaria, 44, 132-138. 
Hajós, Gy. \& Delincée, H. (1983): Structural investigation of radiation-induced aggregates of ribonuclease. Int. J. Radiat. Biol. Re., 44, 333-342.

Hoffmann, K. \& Blüchel, E. (1986): Bestimmung der Tierart von rohem Muskelfleisch anhand der Myoglobinmuster im pH-Gradienten-Gel. Fleischwirtschaft, 66, 916-921.

Imasaki, T., Noshiroya, K., Saitoh, N., Okano, K. \& Yamamoto, K. (2006): Studies of the effect of hydrostatic pressure pretreatment on thermal gelation of chicken myofibrils and pork meat patty. Food Chem., 9, 474-483.

Joo, S.T., Kauffman, R.G., Kim, B.C. \& PARK, G.B. (1999): The relationship of sarcoplasmic and myofibrillar protein solubility to colour and water-holding capacity in porcine longissimus muscle. Meat Sci., 52, $291-297$.

Ko, W.C., JAO, C.L. \& Hsu, K.C. (2003): Effect of hydrostatic pressure on molecular conformation of tilapia (Orechromis niloticus) myosin. J. Food Sci., 68, 1192-1195.

Kretzschmar, U. (1995): Funktionelle Eigenschaften von Sarcoplasmaproteinen. Fleischwirtschaft, 75, 76-79.

Marcos, B., Kerry, J.P. \& Mullen, A.M. (2010): High pressure induced changes on sarcoplasmic protein fraction and quality indicators. Meat Sci., 85, 115-120.

Moreira, S.A., Duarte, R.V., Fernandes, P.A.R., Alves, S.P., Bessa, R.J., Delgadillo, I. \& Saraiva, J.A. (2015): Hyperbaric storage preservation at room temperature using an industrial-scale equipment: Case of two commercial ready-to-eat pre-cooked foods. Innov. Food Sci. Emerg., 32, 29-36.

Parunović, N., Petrović, M., Matekalo-Sverak, V., Radojković, D., Vranić, D. \& Radović, Č. (2012): Cholesterol and total fatty acid content in m. longissimus dorsi of mangalitsa and Swedish landrace. Acta Alimentaria, 41, $161-171$.

SAns, P. \& Combris, P. (2015): World meat consumption patterns: An overview of the last fifty years (1961-2011). Meat Sci., 109, 106-111.

Sun, X.D. \& Holley, R.A. (2010): High hydrostatic pressure effects on the texture of meat and meat products. J. Food Sci., 75, 17-23.

Toldrá, M., Dávila, E., Saguer, E., Fort, N., Salvador, P., Parés, D. \& Carretero, C. (2008): Functional and quality characteristics of the red blood cell fraction from biopreserved porcine blood as influenced by high pressure processing. Meat Sci., 80, 380-388.

ToRnBERG, E. (2005): Effects of heat on meat proteins - Implications on structure and quality of meat products. Meat Sci., 70, 493-508. 